\title{
Waste ceramics as supplementary cementitious material: characterization and utilization
}

\author{
M. Keppert, M. Č́chová, M. Pavlíková, A. Trník, J. Žumár \\ \& R. Černý \\ Faculty of Civil Engineering, Department of Materials Engineering \\ and Chemistry, Czech Technical University in Prague, Czech Republic
}

\begin{abstract}
Materials containing thermally treated clay minerals are well known for their pozzolanity, i.e. ability to react with calcium hydroxide to cementing compounds. Finely ground ceramics have been used as pozzolan since ancient times and nowadays they again attracts attention because of the current effort to utilize waste as secondary raw material. Contrary to other pozzolans (fly ash, metakaolin etc.) ceramics contain not only a reactive phase but also a certain amount of crystalline minerals which do not take part in the hydration process. The paper deals with finely ground ceramic powder generated during production of brick blocks.
\end{abstract}

Keywords: waste ceramics, supplementary cementitious material, mineralogical composition, amorphous phase.

\section{Introduction}

As supplementary cementitious materials (SCM) are a recognized wide group of siliceous or siliceous-aluminous natural and anthropogenic matters which are reactive in alkaline environment and a product of this reaction (pozzolanic reaction in the case of $\mathrm{Ca}(\mathrm{OH})_{2}$ ) are cementing compounds - calcium-silicatehydrates $(\mathrm{CSH})$ and calcium-aluminium-hydrates (CAH). SCMs are known from ancient times when their utilization was the only way to obtain a hydraulic binder. Both natural (volcanic ash) and anthropogenic (calcined clay) pozzolans were used. In that time SCMs were used in combination with lime, today's main application lies in admixing with Portland clinker where SCMs are reducing the clinker production environmental impact, improving durability performance of 
concrete and production reducing costs. Moreover most of SCMs are waste from another technology thus their utilization reduces the waste generation. Calcined clays are one of traditional SCMs, nowadays especially metakaolin (calcined kaolin intentionally produced as SCM) is widely studied as concrete component [1]. An alternative to relatively costly metakaolin can be found in waste ceramic materials. Among the technical ceramics, brick ware is the most widely produced.

There are two sources of waste brick ceramics. The easiest to acquire is the respective product from processing of construction and demolition waste. Main drawback of such recycled ceramic material is variability in composition and properties from place to place and also contamination of recycled "brick fraction" with masonry mortar and render which are diluting the active components of ceramics. Such recycled ceramics is thus suitable just as filler in construction binders [2]. A second - and more valuable - source of waste brick ceramic is technology of brick block calibration by grinding which is introducing recently as response on demand of brick block suitable for thin-layer mortar application [3]. Obviously the grinding dust properties differ from one brick plant to other but the time-constant properties of ceramics from single production site can be assumed in modern factories. The drawback of waste brick ceramics compared to e.g. metakaolin is partial crystallinity while metakaolin is nearly wholly amorphous. The utilization of waste brick ceramics as SCM as concrete component was reported $[4,5]$.

Since properties of waste brick ceramics are highly variable, a characterization, especially the ability to act in pozzolanic reaction, has to be performed. There is not any technical standard applicable for brick ceramics as SCM; the present paper deals with several experimental methods which can be used for characterization and evaluation of waste brick ceramics as SCM intended to be used in Portland cement or lime based composites.

\section{Methods}

Chemical composition of ceramics was examined by X-ray fluorescence spectroscopy (XRF) by help of Thermo ARL 9400 XP device. The phase composition was studied by X-ray diffraction (XRD) by means of PANalytical $X^{\prime}$ Pert PRO system. Quantification of present phases was performed by Rietveld analysis with internal standard (zincite $\mathrm{ZnO}$ ). The pozzolanic activity was determined by standard method [6] where studied waste ceramics was mixed with ordinary Portland cement CEM I 42.5. The particle size distribution was determined by laser diffraction analyser (Fritsch, Analysette 22 MicroTec plus). Conventional grading curve was obtained by help of standard sieves set [7]. Blaine specific surface area was measured according [8]. Simultaneous TG/DSC (thermogravimetry and differential scanning calorimetry) thermal analysis was performed by Setaram calorimeter Labsys Evo under inert atmosphere from ambient temperature to $1000{ }^{\circ} \mathrm{C}$. The presence of $\mathrm{CSH}$ hydrates was checked by FTIR spectroscopy (Nicolet 6700, Thermo Fischer Scientific). The ceramics lime reactivity and influence of waste ceramics on strength of lime-based 
materials was examined by help of measurement of compressive strength [9] of pastes prepared from various portions of slaked lime (type CL $90 \mathrm{~S}$ ) and waste ceramics. The content of waste ceramics varied from 0 to $70 \%$ (in dry state), the rest was slaked lime. The amount of water in pastes was changed in order to obtain a constant consistency (paste spill $160 \mathrm{~mm}$, [10]). The demoulded specimens of pastes were stored in laboratory conditions and kept wet by water spraying till testing. The strength was measured after 28 days and 6 months of curing.

\section{Results and discussion}

The ability of a potential Supplementary Cementitious Material to take part in the hydration process depends on its chemical and physical properties. Total chemical composition of studied ceramics (Tab. 1) can be assumed as common for red clay bricks; just content of alkaline earth metals ( $\mathrm{Ca}$ and $\mathrm{Mg}$ ) is somewhat higher. Positive, but expectable was low content of sulphates and any present chlorides.

Table 1: Chemical composition of whole ceramics and of its amorphous portion.

\begin{tabular}{|c|c|c|}
\hline & $\begin{array}{c}\text { Whole } \\
\text { ceramics (wt. } \\
\% \text { ) }\end{array}$ & $\begin{array}{c}\text { Amorphous } \\
\text { part } \\
\text { (wt.\%) }\end{array}$ \\
\hline $\mathrm{SiO}_{2}$ & 51.3 & 24.4 \\
\hline $\mathrm{Al}_{2} \mathrm{O}_{3}$ & 20.0 & 33.7 \\
\hline $\mathrm{Fe}_{2} \mathrm{O}_{3}$ & 6.0 & 7.1 \\
\hline $\mathrm{CaO}$ & 11.5 & 19.0 \\
\hline $\mathrm{MgO}$ & 4.5 & 7.9 \\
\hline $\mathrm{K}_{2} \mathrm{O}$ & 3.2 & 2.3 \\
\hline $\mathrm{Na}_{2} \mathrm{O}$ & 1.3 & 1.1 \\
\hline $\mathrm{TiO}_{2}$ & 0.8 & 1.5 \\
\hline $\mathrm{SO}_{3}$ & 1.0 & 1.2 \\
\hline
\end{tabular}

Unfortunately such chemical analysis does not say anything about reactivity of ceramics in alkaline environment. There is important content of a reactive amorphous portion because the rest of ceramics is formed by crystalline minerals which are acting just as a passive component (filler). The quantitative XRD analysis (Tab. 2) revealed that content of amorphous portion is 46.7\%; the resting crystalline part is consisting of quartz, feldspars, micas and other minerals. The amorphous portion should contain preferably $\mathrm{SiO}_{2}$ and $\mathrm{Al}_{2} \mathrm{O}_{3}$ since these oxides can form cementing $\mathrm{CSH}$ and $\mathrm{CAH}$ hydrates. The chemical composition of amorphous portion of ceramics was estimated by help of knowledge of chemical composition and content of individual minerals 
(of known composition); the contents of particular oxides in amorphous matter were calculated as difference between total content in ceramics and amount present in detected and quantified minerals (Table 1). Obviously it is just estimation since XRD is not identifying all phases and all entering figures are containing certain error. Nevertheless it was found that $\mathrm{Al}_{2} \mathrm{O}_{3}$ forms about $34 \%$ and $\mathrm{SiO}_{2} 24 \%$ of amorphous portion. Other important oxides found in amorphous part are $\mathrm{CaO}$ and $\mathrm{MgO}$ which are not valuable in this material since they are "diluting" the reactive part of ceramics.

Table 2: Quantitative phase composition (wt.\%).

\begin{tabular}{|c|c|c|}
\hline \multicolumn{2}{|c|}{ Amorphous matter } & 46.7 \\
\hline \multicolumn{2}{|l|}{ Quartz } & 23.6 \\
\hline \multirow{3}{*}{$\begin{array}{l}\frac{\omega}{\sqrt{0}} \\
\frac{0}{0} \\
\frac{0}{0} \\
\frac{0}{1} \\
\leftarrow\end{array}$} & Albite & 6.5 \\
\hline & Microcline & 7.2 \\
\hline & Orthoclase & 2.8 \\
\hline \multirow{2}{*}{$\stackrel{\mathbb{O}}{\sum}$} & Biotite & 0.9 \\
\hline & Muscovite & 2.6 \\
\hline \multirow{2}{*}{ 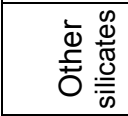 } & Ackermanite & 4.4 \\
\hline & Hedenbergite & 3.8 \\
\hline \multicolumn{2}{|l|}{ Hematite } & 1.4 \\
\hline \multicolumn{2}{|l|}{ Ettringite } & 0.4 \\
\hline
\end{tabular}

Among the physical characteristics the particle size distribution is very important when a SCM is evaluated. Obviously high fineness of pozzolanic component is desired. Advantage of ceramics from bricks grinding is its natural relatively high fineness thanks to the production process and thus there in not any need to crush or mill the particles. The waste ceramics particles were studied by two common methods. The laser diffraction analysis (Fig. 1) reported presence of particles of diameter between 0.1 and $100 \mu \mathrm{m}$ with $\mathrm{d}_{50}$ to be $7.5 \mu \mathrm{m}$. Such distribution has been close to Portland cement but for ceramics it was somewhat broader. The values of Blaine specific surface area corresponded to that: ceramics $665 \mathrm{~m}^{2} / \mathrm{kg}$, OPC is usually about $300-350 \mathrm{~m}^{2} / \mathrm{kg}$. The Blaine specific surface area of lime hydrate used for testing of ceramics influence on strength was about one order of magnitude higher when compared to ceramics. Unfortunately the laser diffraction analysis was not able to detect and quantify any larger particles. Even though the waste ceramics looked like a fine powder it contained certain amount of particles retained on $2 \mathrm{~mm}$ sieve (Fig. 2). Such large particles can represent weak points of final composite since its low strength which can reduce the strength of composite. The residue on $0.045 \mu \mathrm{m}$ sieve was $69.9 \%$ what is too much with respect to standard [11] applicable for fly ash as pozzolanic material for concrete (requirement is $40 \%$ ). 


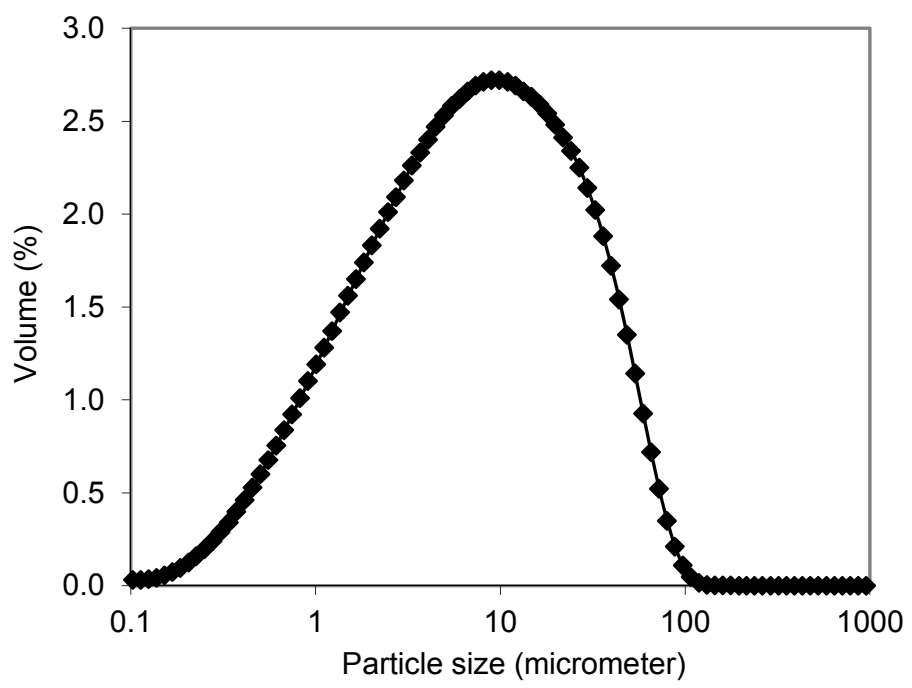

Figure 1: Particle size distribution obtained by laser diffraction analyser.

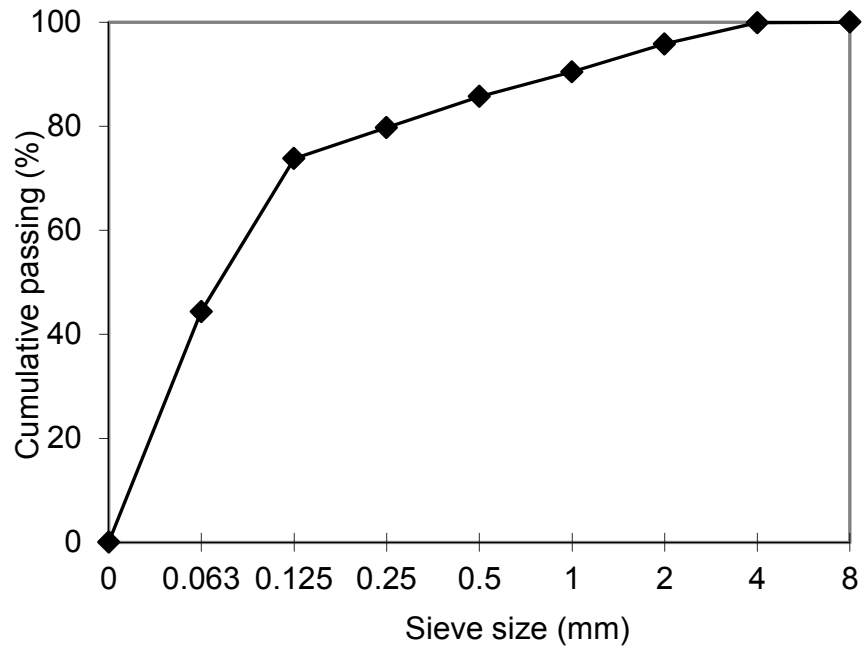

Figure 2: Grading curve of waste ceramics.

The reactivity of ceramics with $\mathrm{Ca}(\mathrm{OH})_{2}$ can be tested by various modifications of the Chapelle test where the amount of $\mathrm{Ca}(\mathrm{OH})_{2}$ reacted with a pozzolana is measured. In this work the standard method [6] was used with a positive result. Since this method is just indicative (pozzolanic reaction yes/no) further methods were used in order to prove the presence of products of 
pozzolanic reaction. Infra-red spectroscopy can be used for identification of chemical bonds especially in oxygen containing functional groups. FTIR spectroscopy (Fig. 3) of 6-month cures samples of pure lime and ceramics:lime 1:1 demonstrated by a strong hump between 1200 and $900 \mathrm{~cm}^{-1}$ presence of CSH hydrates in sample with ceramics. The peak at $1400 \mathrm{~cm}^{-1}$ in both samples corresponds to carbonate anion.

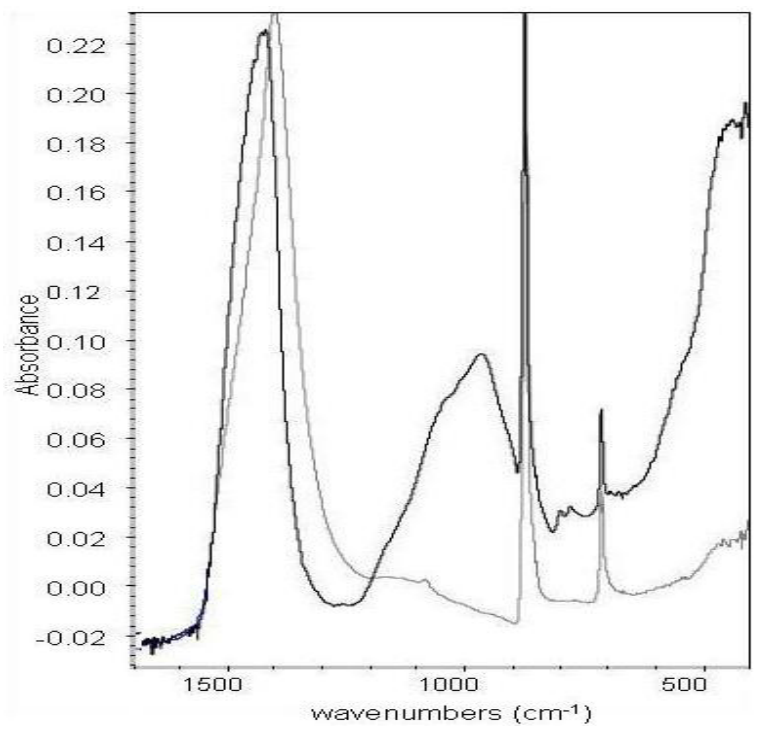

Figure 3: FTIR spectra of ceramics:lime 1:1 mixture after 6 months of curing (black line) and pure lime (grey line).

Complex thermal analysis (Fig. 4) of cured mixture ceramics:lime 1:1 showed that this sample contained after 6 months of curing about $20 \mathrm{wt} . \%$ of $\mathrm{Ca}(\mathrm{OH})_{2}$ (DSC peak at $500^{\circ} \mathrm{C}$ ) and obviously also app. $32 \mathrm{wt.} \%$ of $\mathrm{CaCO}_{3}(\mathrm{DSC}$ peak at $820^{\circ} \mathrm{C}$ ). Several unidentified products of ceramics hydration decomposed at temperature between 100 to $300^{\circ} \mathrm{C}$. Their nature and concentration were not possible to be determined but since unreacted ceramics was not detectable by thermal analysis this peaks can be considered as evidence of pozzolanic reaction of studied ceramics.

Unfortunately the methods evidencing the pozzolanic reaction do not provide any information about optimum mixing ratio between ceramics and lime with respect to achievement of the highest cementing ability. The proper dosing of ceramics and $\mathrm{Ca}(\mathrm{OH})_{2}$ can be estimated by help of graphical expression of composition of studied materials (Fig. 5). The chemical composition of whole ceramics and its amorphous part was normalized to $100 \%$ of principal components $\left(\mathrm{SiO}_{2}, \mathrm{CaO}+\mathrm{MgO}, \mathrm{Al}_{2} \mathrm{O}_{3}+\mathrm{Fe}_{2} \mathrm{O}_{3}\right)$ and plotted. The line between $\mathrm{CaO}+\mathrm{MgO}$ corner and "amorphous part" represent composition of mixtures lime:ceramics with increasing content of ceramics. Only the composition of amorphous part was taken into account since this part of ceramics can react with 


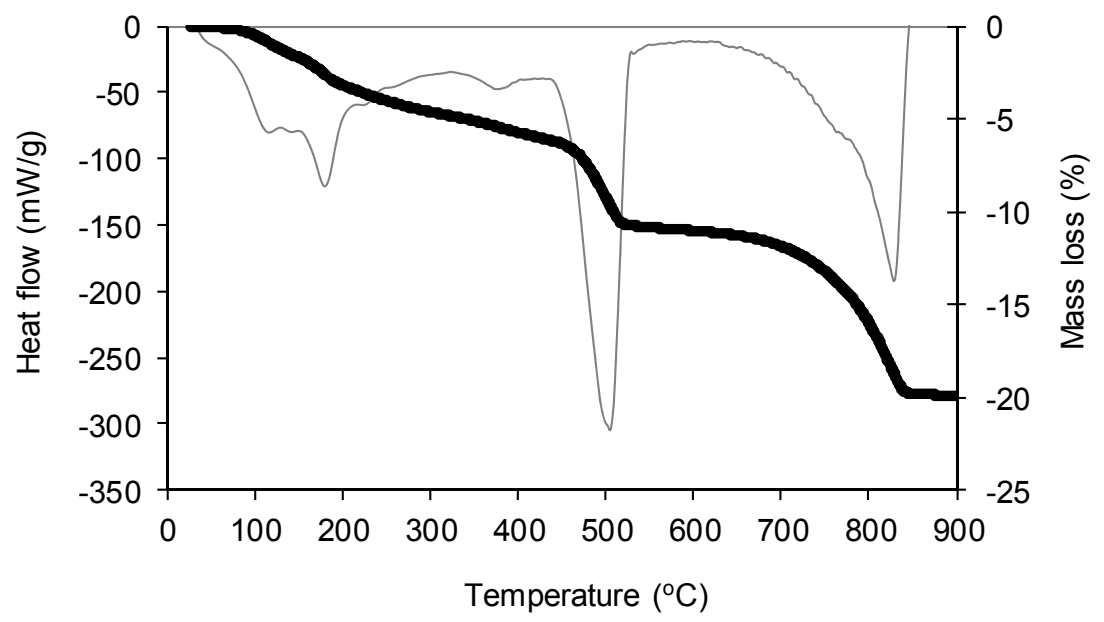

Figure 4: DSC and TG analysis of ceramics:lime 1:1 mixture after 6 months of curing (TG thick black line, DSC grey line).

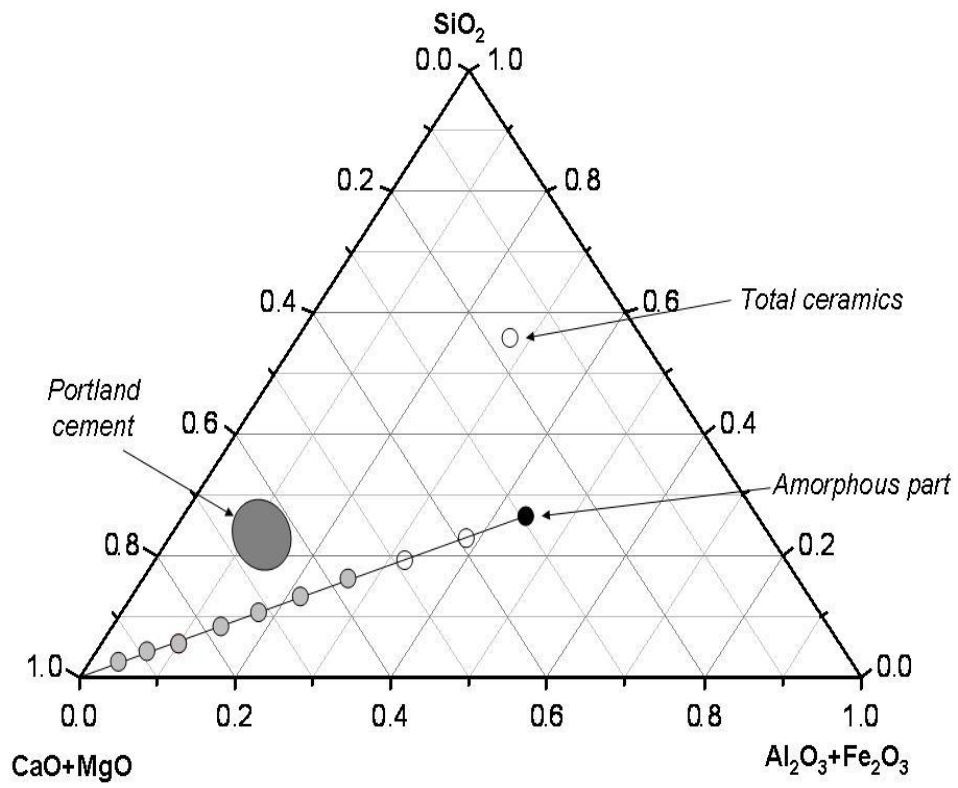

Figure 5: Graphical expression of composition of whole ceramics, its amorphous part and tested (grey circles) mixtures ceramics:lime. 
lime. The oxide composition of Portland cement was marked in diagram since this area is characterized by optimum ratio between lime and hydraulic oxides and thus achievement of this composition by lime:ceramics mixture may provide good strength and durability.

This assumption was tested by measurement of compressive strength of pastes with increasing amount of ceramics after 1 and 6 months of curing (Fig. 6). The strength of pure lime was the lowest and the admixing of ceramics caused its increase. It was noticeable especially from $30 \%$ content of ceramics, the mixture containing $70 \%$ of ceramics and $30 \%$ of lime reached the highest strength. Composition of mixtures with 50,60 and 70\% of ceramics roughly corresponded with Portland cement composition. Moreover the pozzolanic reaction was indicated by significant strength increase in time since generally the pozzolanic reaction is relatively slow.

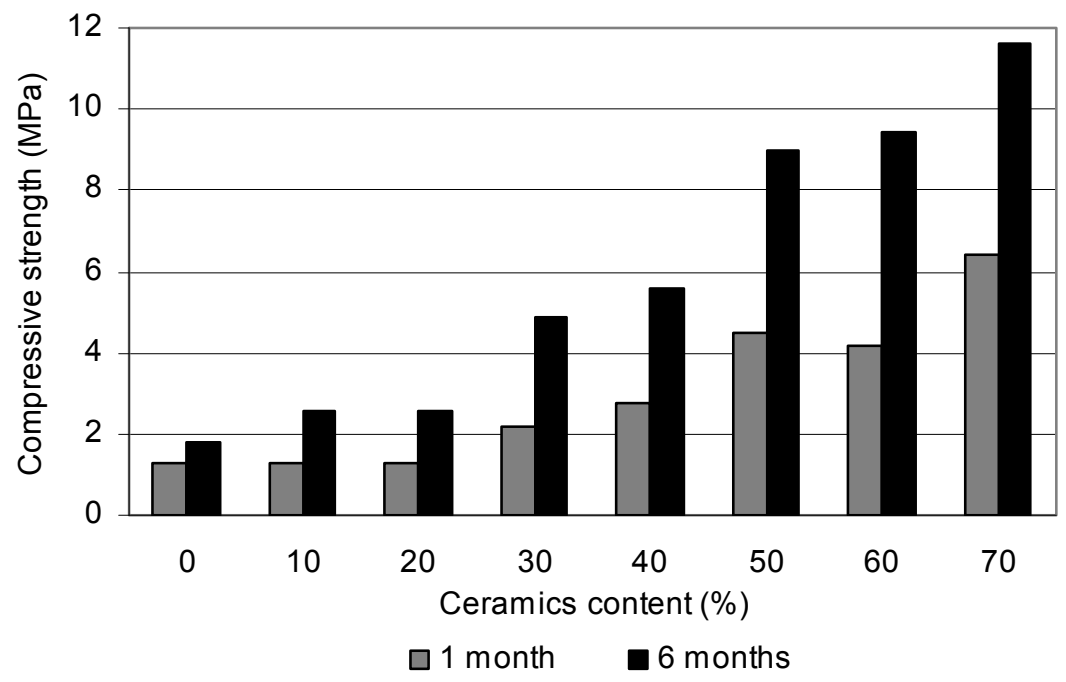

Figure 6: Time evolution of compressive strength of pastes with various content of ceramics.

\section{Conclusions}

The possibility of application of waste brick ceramics generated by brick blocks grinding as Supplementary Cementitious Material was studied. 46.7\% of ceramics was formed by amorphous matter, the rest was crystalline. Even though the ceramics particles were coarser than is the standard requirement on active admixtures and the ceramics contained relatively high amount of $\mathrm{CaO}$ and $\mathrm{MgO}$ the pozzolanic reaction between ceramics and lime was evidenced. The optimum dosing (based on the compressive strength measurement of pastes) of studied ceramics to $\mathrm{Ca}(\mathrm{OH})_{2}$ was found to be 50 to $70 \mathrm{wt} \%$ of ceramics and 30 to 
50 wt.\% of slaked lime. The strength was increasing with time what is again evidencing the pozzolanic reaction of studied ceramics.

\section{Acknowledgement}

This research has been supported by the Ministry of Industry and Trade of the Czech Republic within the project No. FR-TI4/014 "Solution of surface layers of brick buildings using brick rubbing dust".

\section{References}

[1] E. Vejmelková, M. Keppert, S. Grzeszczyk, B. Skalinski, R. Černý, Properties of self-compacting concrete mixtures containing metakaolin and blast furnace slag. Construction and Building Materials, 2011, 25, 1325-1331.

[2] J.R. Jimenez, J. Ayuso, M. Lopez, J.M. Fernandez, J. de Brito, Use of fine recycled aggregates from ceramic waste in masonry mortar manufacturing. Construction and Building Materials, 2013, 40, 679-690.

[3] Z. Pavlík, M. Jerman, A. Trník, V. Kočí, R. Černý, Effective thermal conductivity of hollow bricks with cavities filled by air and expanded polystyrene, Journal of Building Physics, 2014, 37, 439-448.

[4] M. O'Farrell, B.B. Sabir, S. Wild, Strength and chemical resistance of mortars containing brick manufacturing clays subjected to different treatments, Cement and Concrete Composites, 2006, 28, 790-799.

[5] E. Vejmelková, M. Keppert, P. Rovnaníková, M. Ondráček, Z. Keršner, R. Černý, Properties of high performance concrete containing fine-ground ceramics as supplementary cementitious material, Cement and Concrete Composites, 2012, 34, 55-61.

[6] ČSN EN 196-5, Methods of testing cement - Part 5: Pozzolanicity test for pozzolanic cement. Czech Standardization Institute, 2011.

[7] ČSN EN 933-2, Tests for geometrical properties of aggregates. Determination of particle size distribution. Test sieves, nominal size of apertures. Czech Standardization Institute, 1997.

[8] CSN EN 196-6, Methods of testing cement - Part 6: Determination of fineness. Czech Standardization Institute, 2011.

[9] ČSN EN 12 390-3, Testing hardened concrete. Compressive strength of test specimens. Czech Standardization Institute, 2002.

[10] ČSN EN 1015-3, Methods of test for mortar for masonry. Determination of consistence of fresh mortar (by flow table). Czech Standardization Institute, 2001.

[11] ČSN EN 450, Fly ash for concrete. Definition, specifications and conformity criteria. Czech Standardization Institute, 2001. 